\title{
Efeito do Concentrado de Plasma em Falhas Ósseas Provocadas em Fêmures, de Camundongos como Estimulação de Formação Óssea. Estudo Experimental
}

Effect of Plasma Concentrate on Bone Defects Induced in Mice Femurs via Stimulation of Bone Formation: An Experimental Study

\author{
Alberto Tesconi Croci ${ }^{1}$, Olavo Pires de Camargo ${ }^{1}$, George Bitar ${ }^{2}$, \\ Silvio luiz Borges Pereira ${ }^{3}$, Marcelo Moreira ${ }^{4}$, Sinval de Freitas JR. ${ }^{4}$
}

\section{RESUMO}

Os autores estudam experimentalmente o efeito do concentrado de plasma na estimulação óssea em camundongos. Foram utilizados dez camundongos isogênicos de linhagem gioto, onde após a coleta do sangue periférico de um camundongo, foi centrifugado este sangue e obtido um concentrado de plasma; foi utilizado o concentrado de plasma em falhas ósseas na região distal do fêmur, alternando-se os lados direito e esquerdo, sendo um lado com falha óssea isolada e o outro com falha óssea mais o concentrado de plasma e analisados quantitativamente e qualitativamente. Observou-se que o plasma não leva à estimulação da formação do calo ósseo, não ocorrendo aumento do processo inflamatório, e havendo apenas uma tendência a formar mais matriz óssea com o seu uso.

Descritores: Camundongos de cepas endogâmicas; Plasma; Calo ósseo; Matriz óssea.

\section{INTRODUÇÃO}

Tal como os outros tecidos musculoesqueléticos o osso é composto por células mesenquimais inclusas dentro de uma matriz extracelular abundante ${ }^{(1)}$. Diversamente dos outros tecidos, a matriz óssea contém mineral que confere ao tecido grande resistência e rigidez sob condições de carga ${ }^{(1)}$.

O principal componente orgânico da matriz óssea é o colágeno tipo I; este dá ao osso uma grande resistência às forças tensionais ${ }^{(2)}$. O osso possui um elaborado suprimento sangüíneo e também contém nervos, vasos sangüíneos e linfáticos. 0 periósteo é constituindo por duas camadas: uma fibrosa externa e uma interna mais celular e vascular; o periósteo cobre as superfícies ósseas externas e participa na consolidação das fra-

\section{SUMMARY}

In this trial the authors investigated the effect of plasma concentrate on bone callus formation in mice. Ten mice of the Gioto isogenic mouse strain were used; samples of peripheral blood of each mouse were collected and centrifuged, giving a plasma concentrate that was used to investigate bone defects at the distal region of the femur; the right and left sides were used alternately, and one side showed a single bone defect; the plasma concentrate was analyzed both qualitatively and quantitatively. It was noticed that the plasma concentrate did not lead to any stimulation of bone callus formation and no inflammatory effect increase has occurred; also, its use showed only a tendency to increase bone matrix formation.

Key words: Mice, Inbred strains; Plasma; Bony callus, Bone matrix.

\section{INTRODUCTION}

The same as with other musculoskeletal tissues, the bone tissue is formed by mesenchymal cells inserted into an abundant extracellular matrix ${ }^{(1)}$. Unlike other tissues, the bone matrix contains minerals that provide the tissue with high strength and rigidity under load conditions ${ }^{(1)}$.

The main organic component of the bone matrix is type 1 collagen, which provides the bone with high strength to tensional forces (2). Besides nerves, blood vessels and lymphatic vessels, bones present a complex blood supply. The periosteum consists of two layers, one external fibrous layer and one internal, more fibrous and vascular layer; the periosteum coats the external bone surfaces and participates in the fracture healing. The
Trabalho realizado no Serviço de Residência Médica em Ortopedia e Traumatologia na Santa Casa de São Vicente e Faculdade Ciências Médicas de Santos - UNILUS

1 - Professor Associado do Departamento de Ortopedia e Traumatologia da FMUSP. 2 - Chefe do Serviço de Residência Médica de Ortopedia e Traumatologia na Santa Casa de São Vicente - UNILUS

3 - Preceptor do Serviço de Residência Médica de Ortopedia e Traumatologia na Santa Casa de São Vicente - UNILUS

4 - Ex-residente de Ortopedia e Traumatologia da Santa Casa de São Vicente UNILUS.

Endereço para correspondência: Rua Dr. Franco da Rocha, 215 ap31 - Perdizes - São Paulo. CEP 05015.040.
Work performed at the Medical Residence Service on Orthopedics and Traumatology, Santa Casa de Sao Vicente and Faculty of Medical Science of Santos (UNILUS), SP, Brazil

1 - Associate Professor, Department of Orthopedics and Traumatology, Faculty of Medicine of the University of Sao Paulo (FMUSP).

2 - Head, Service of Medical Residence in Orthopedics and Traumatology, Santa Casa de Sao Vicente, (UNILUS).

3 - Preceptor, Medical Residence Service of Orthopedics and Traumatology, Santa 3 - Preceptor, Medical Residence

4 - Ex resident of Orthopedics and Traumatology, Santa Casa de Sao Vicente, (UNILUS).

Address: Rua Dr. Franco da Rocha, 215 - ap 31 - Perdizes - São Paulo, SP 05015-040 - Brazil 
turas. O periósteo é mais espesso, e celular. Nos lactentes e crianças apresenta um suprimento sangüíneo mais elaborado do que nos adultos. Talvez em virtude destas diferenças, o periósteo nas crianças é mais ativo na consolidação de muitas fraturas ${ }^{(1)}$.

O osso humano se apresenta em duas formas: o osso cortical ou compacto e osso esponjoso ou trabecular. As diáfises dos ossos longos possuem praticamente só osso cortical. As metáfises por sua vez e a maioria dos ossos curtos e planos apresentam paredes relativamente finas de osso cortical com grandes volumes de osso esponjoso. Estas diferenças na distribuição de osso cortical e esponjoso causam diferenças na consolidação óssea ${ }^{(1)}$.

Os dois tipos ósseos podem ser diferenciados pelas propriedades mecânicas e biológicas: o osso traçado ou imaturo e o osso lamelar ou maduro. O osso trançado forma o esqueleto embrionário e é substituído por osso lamelar à medida que o esqueleto se desenvolve(2). O osso trançado também forma o tecido inicial de reparação da fratura e é substituído por osso lamelar à medida que ocorre a remodelação. Comparado com o osso lamelar, o trançado tem uma velocidade mais rápida de deposição e reabsorção óssea. Há um padrão trançado irregular de fibrilas colágenas na matriz com aproximadamente quatro vezes mais osteócitos por unidade de volume que o normal, e um padrão irregular de mineralização da matriz. A freqüente formação em "colcha de retalhos" do osso trançado e o padrão de mineralização em focos criam uma aparência na radiográfica irregular que distingue o osso trançado encontrado no calo de fratura do osso lamelar. Em virtude da falta de orientação das suas fibrilas colágenas a mineralização irregular e a concentração relativamente alta de células e água, o osso trançado é menos rígido e mais facilmente deformado do que o osso lamelar(3).

Uma fratura começa o seu processo de consolidação assim que osso se quebra, e se as condições forem favoráveis, este processo se dá por uma série de fases até que o osso esteja totalmente consolidado.

As características histológicas de reparação de uma fratura em vários intervalos após a lesão foram bem descritas que se referiam principalmente às fraturas de várias costelas em coeIhos, e estas evidências sugerem que o processo de reparação seja semelhante ao encontrado no homem. Contudo, deve-se levar em conta que o tipo de consolidação não é o mesmo e constante para todos os ossos em todas as circunstâncias. A reparação de um osso tubular difere muito daquela de um osso esponjoso, e o tipo de consolidação de um segmento é provavelmente influenciado por fatores como a fixação rígida dos fragmentos e a perfeição da coaptação ${ }^{(7,8)}$.

Podemos considerar o processo de consolidação de um osso tubular fraturado como ocorrendo em cinco estágios: 1. Hematoma, 2. Proliferação subperiosteal e endosteal, 3. Calo, 4. Estágio de consolidação e 5. Remodelação. Devemos enfatizar, no entanto, que estes estágios não são demarcados de maneira nítida, e que dois ou mais estágios de consolidação podem ocorrer ao mesmo tempo em diferentes partes do osso(3).

Em uma fratura o sangue extravasa através dos vasos rotos e forma-se um hematoma entre as áreas da superfície fraturada ao seu redor. O hematoma fica quase totalmente contido no periosteum is thicker, and cellular in character. In breast-fed babies, as well as in small children, it presents a more complex blood supply as compared with adults. Perhaps due to these differences, in children the periosteum is more active as regards the healing of many types of fractures (1).

There are two types of human bones, namely the cortical (compact) bone and the spongy (trabecular) bone. Long bones diaphyses consist virtually of cortical bone only. Metaphyses, on their turn, as well as most short and plane bones, have relatively thin-walled cortical bones, with large volumes of spongy bone. These differences in the distribution of cortical and spongy bones will cause differences in bone healing (1).

According to their mechanical and biological properties, bones may be classified into two types, namely, the woven or immature bone and the lamellar or mature bone. The woven bone forms the embryonal bone and is replaced by lamellar bone as the skeleton develops ${ }^{(2)}$. Also, the woven bone forms the first tissue of the fracture repair and is replaced by lamellar bone as remodeling occurs. As compared to the lamellar bone, the woven bone has a higher deposition and resorption speed. The bone matrix has a woven bone with an irregular pattern of collagen fibrils containing approximately four times more osteocytes per volume unit than normal, as well as an irregular matrix mineralization pattern. The frequent formation of a sort of patchwork in the woven bone, plus the mineralization pattern in the form of focuses create an irregular radiographic appearance that distinguishes the woven irregular bone found in the fracture callus from the lamellar bone. Due to the lack of orientation of its collagen fibrils, the irregular mineralization and a relatively high cell concentration and water content, the woven bone is less rigid and more easily deformed than the lamellar bone ${ }^{(3)}$.

A fracture will start its healing process as soon as the bone is broken and, under favorable conditions, this process follows a series of stages until the bone is completely healed.

Histological characteristics of fracture repair in various time points after the injury were well described and referred mainly to fractures of several ribs in rabbits; such evidences suggest that the repairment process is similar to that found in humans. However, it should be taken into account that the type of healing is not the same for all bones under all circumstances, besides not being constant. The repair of a tubular bone is very different from that of a spongy bone and the type of healing of a segment is likely to be influenced by factors such as the rigid fixation of the fragments and the perfection of the coaptation $(7,8)$.

The healing process of a fractured tubular bone occurs in five stages: 1. hematoma; 2. subperiosteal and endosteal proliferation; 3. callus formation; 4. healing; and 5. remodeling. However, it should be emphasized that these stages have no sharp limits and that two or more healing stages may occur simultaneously in different portions of the bone ${ }^{(3)}$.

In any fracture, blood will overflow through the broken vessels as a hematoma is formed between the areas of the broken surface around it. The hematoma is almost totally contained in the surrounding periosteum and may be shifted or removed from the ends of the bone to different extents. As the periosteum is removed, the hematoma may overflow into the surrounding soft tissues and ultimately, will be contained by muscles, fascias, and skin (7). 
periósteo circundante, e pode ser deslocado ou retirado das extremidades do osso em menor ou maior intensidade. Quando o periósteo é retirado, o hematoma pode extravasar para os tecidos moles adjacentes ficando em última instância, contido por músculos, fáscias e pele ${ }^{(7)}$.

A fratura inevitavelmente rompe a maior parte dos capilares que correm longitudinalmente no osso compacto, e o anel ósseo imediatamente adjacente a cada um dos lados da fratura se tornam isquêmicos em extensão variada, geralmente alguns milímetros. Sem suprimento sangüíneo, os osteócitos próximos da superfície fraturada morrem.

A característica mais óbvia nos estágios iniciais da reparação é a proliferação de células da superfície profunda do periósteo próximo à fratura. Tais células são as precursoras dos osteoblastos, que posteriormente deverão sedimentar a substância intercelular. Formam um colar de tecido ativo que circunda cada fragmento e cresce em direção ao outro fragmento. Deve-se ressaltar que este tecido celular não é formado por organização do hematoma coagulado da fratura. Na verdade o sangue coagulado tem participação nula ou muito pequena no processo de reparação; este é substituído pelo tecido de proliferação e absorvido(5).

Concomitantemente à proliferação subperiosteal ocorre a atividade celular dentro do canal medular onde as células que proliferam parecem ser derivadas do endósteo e do tecidos contidos na medular de cada fragmento. Este tecido também se prolifera até fundir-se ao tecido semelhante que cresce do outro fragmento.

Ilhotas de cartilagem podem ser encontradas no tecido celular que cresce dentro e fora do osso, formando uma ponte entre os fragmentos. A cartilagem aparece em quantidade variável sendo às vezes abundante, e em outras, pode estar ausente. Evidentemente, não é um elemento essencial no processo de consolidação( ${ }^{(3)}$.

À medida que o tecido celular cresce de cada fragmento, este amadurece, e as células básicas dão origem aos osteoblastos, e em alguns pontos aos condroblastos que formam a cartilagem a que já nos referimos. Os osteoblastos depositam uma matriz intercelular de colágeno e polissacarídeos que logo se torna impregnada de sais de cálcio para formar o osso não amadurecido do calo da fratura. Este, por sua vez, devido à sua textura foi denominado osso "primário"(3).

A formação desta ponte de osso primário proporciona rigidez evidente à fratura, e quando o osso lesado é superficial o calo pode ser sentido como uma massa rija ao redor da fratura. O calo ósseo ou osso primário é também visível nas radiografias e dá a primeira indicação radiográfica de que a fratura está se consolidando(2).

O osso primário que forma o calo primário transforma-se gradualmente pela ação dos osteoblastos em um osso mais amadurecido, com estrutura lamelar típica.

Quando a consolidação está completa, o osso recém formado forma em geral, um colar bulboso que circunda o osso e oblitera o canal medular. O tamanho do calo varia de caso para caso. Tende a ser grande nos casos onde tenha ocorrido um deslocamento periosteal extenso, um hematoma grande, ou ainda um desvio grande dos fragmentos ósseos. É em geral pequeno quando os fragmentos ósseos estiverem em posição
Inevitably, a fracture will break the most part of the capillaries running along the compact bone, and the bone ring immediately adjacent to each side of the fracture will become ischemic to a certain extent, usually a few millimeters. With no blood supply, the osteocytes located near the fractured surface will die.

The most obvious characteristic of the early stages of a repair is the proliferation of cells in the deep surface of the periosteum close to the fracture. Such cells are the precursors of the osteoblasts that later must sediment the intercellular substance. The cells form a collar of active tissue that surrounds each fragment and grows towards another fragment. It is worth noticing that this cellular tissue is not the result of organization of the fracture's coagulate hematoma. In fact, the coagulate blood has little or no participation at all in the process of repairment and is replaced by the proliferation tissue, to be finally reabsorbed (5).

Concomitantly with subperiosteal proliferation, cell activity occurs inside the medullar canal where proliferating cells seem to derive from the endosteum and tissues contained in the medulla of each fragment. This tissue also proliferates until it merges with the similar tissue that grows from the other fragment.

Islets of cartilage may be found in the cellular tissue that grows inside and outside the bone, forming a bridge between the fragments. Cartilage appears in different amounts ranging from absence to very large amounts. Obviously, it is not an essential element in the healing process ${ }^{(3)}$.

As the cellular tissue grows from each fragment, the fragment will mature and the basic cells will give origin to osteoblasts and, at some points, to chondroblasts that form the above-mentioned cartilage. Osteoblasts deposit an intercellular matrix formed by collagen and polysaccharide that soon becomes impregnated with calcium salts to form the immature bone of the fracture callus. Due to its texture, this callus was named "primary" bone (3).

The formation of this bridge of primary bone provides the fracture with obvious rigidity, so when the injured bone is superficial, the callus may be felt as a rigid mass surrounding the fracture. The bone callus or primary bone can also be seen in radiographs and provides the first radiographic evidence that the fracture starts to heal(2).

By the action of osteoblasts, the primary bone forming the primary callus is gradually converted into more mature bone with typical lamellar structure.

Once the healing is complete, usually the freshly made bone forms a bulbous collar that surrounds the bone and obliterates the medullar canal. The size of the callus varies from case to case, tending to be large where an extended periosteal displacement, a large hematoma or, yet, a large displacement of bone fragments has occurred. It is usually small when the bone fragments are in anatomical position, particularly if the fragments are rigidly fixed by a screwed metal plate or by intramedullar fixation (7).

The exuberant callus is rather common in children, since in them the periosteum is easily displaced from the bone by extravased blood, thus allowing bone to be formed in its interior.

In the months that follow the healing, the bone is gradually reinforced along the force lines at the expense of the excess bone existing outside the force lines, which is slowly removed. This unnoticeable remodeling process persists in constant activity in all bones for the rest of our lives, although it becomes specially 
anatômica e especialmente quando os fragmentos forem rigidamente fixados por uma placa de metal com parafusos ou por intramedular ${ }^{(7)}$.

O calo exuberante é comum em crianças, pois o periósteo é facilmente deslocado do osso pelo sangue extravasado, permitindo assim que o osso se forme em sua parte interna.

Nos meses que se seguem à consolidação o osso é gradualmente reforçado ao longo das linhas de força à custa do excesso de osso por fora das linhas de força que é lentamente removida. Este processo imperceptível de remodelação está em atividade constante em todos os ossos durante a vida toda, porém se torna especialmente acentuado e evidente após uma fratura.

A consolidação de um osso esponjoso fraturado segue um padrão diferente daquela do osso cortical. Como o osso tem uma textura esponjosa uniforme e não tem canal medular, há uma área de contato mais ampla entre os fragmentos que é a trama de trabéculas que permite uma penetração mais fácil do tecido ósseo e sua formação. A consolidação pode ocorrer diretamente entre as superfícies dos ossos e não precisa ocorrer através do calo externo ou do calo endosteal como em um osso cortical.

Evidenciando isso, Trueta(10), observa que as células primitivas indiferenciadas podem se transformar, dando origem a osteoblastos sob a influência de substâncias osteoindutoras. A proteína óssea morfogenéticas (BMP - bone morphogenetic protein) apresenta tal característica, mas torna-se ineficaz em estimular essa resposta sem um carreador, pois se difunde muito rapidamente em sítios heterotópicos antes que possa ocorrer a osteoindução ${ }^{(11)}$

Croci(3) em 1997, em revisão da literatura, descreve que há trabalhos comprovando a obtenção desta proteína não colágena por desmineralização ácida do osso de bovinos e atualmente de outros animais e humanos (BMP - "bone morphogenetic protein"). Esta teria ação sobre quatro etapas de diferenciação citoespecífica com a ativação e proliferação de células do mesênquima, a formação de cartilagem, a formação de osso primitivo e a formação de osso lamelar. A quantidade de osso neoformado é diretamente proporcional à quantidade dessa proteína. Porém a difusão nos tecidos é limitada. Deve-se ressaltar que o papel da BMP na consolidação óssea só foi estudado experimentalmente; além disso, a etapa em que deva ser administrada com intuito de induzir resposta osteogênica apreciável ainda não foi comprovada.

Vários estudos derivaram da aplicação da BMP, dentre os quais os que realizam implantes com BMP associados com a utilização de medula óssea, com resultados de consolidação mais rápida, provavelmente devido à presença na medula óssea de células precursoras osteogênicas ou células mesenquimais que respondem ao estímulo da $\mathrm{BMP}^{(12)}$.

\section{CASUÍSTICA}

São usados neste trabalho 10 camundongos isogênicos da linhagem gioto, provenientes do Biotério da Faculdade de Ciências Médicas Lusíadas de Santos.

Estes animais são colocados em engradados separados, numerados de 01 a 10 e submetidos aos procedimentos cirúr- noticed and evident after a fracture.

The healing of a fractured spongy bone follows a pattern that is different from that of a cortical bone. Since the bone has a uniform spongy texture and no medullar canal, a more ample contact area exists among the fragments, that is, the trabecular weave that allows easier penetration and formation of bone tissue. The healing may occur directly between the surfaces of the bones and does not require neither the external callus nor the endosteal callus to occur, as is the case with cortical bones.

Trueta (10) emphasized this by observing that primitive nondifferentiated cells may be converted into osteoblasts under the influence of osteoinductive substances. The morphogenetic bone protein has such characteristic but, without a carrier, is not able to stimulate this response, since it will spread too quickly through heterotopic sites before osteoinduction can occur (11).

In a 1997 literature review, Croci(3) describes studies proving that this non-collagen protein is obtained by acid demineralization of bovine bone and, currently, of bones from other animals and from humans, such as bone morphogenetic protein or BMP. This protein would act upon four cell-specific differentiating stages, namely, activation and proliferation of mesenchymal cells, cartilage formation, primitive bone formation and lamellar bone formation. The amount of newly formed bone is directly proportional to the amount of this protein, although its diffusion through the tissues is limited. It must be emphasized that the role of the BMP in bone healing was studied experimentally only; moreover, the stage during which it should be administered with the purpose of inducing a considerable osteogenic response is not proven yet.

Many studies were based on the use of BMP, including the ones that used transplantations with BMP combined with marrow bone, with quicker healing results, probably due to the presence in the bone marrow of osteogenic precursor cells or mesenchymal cells that respond to stimulation by BMP ${ }^{(12)}$.

\section{CASES}

Ten mice of the Gioto isogenic mouse strain were used, provided by the Bioterium of the Lusiadas Faculty of Medical Science of Santos.

Each animal was placed in a separate cage numbered from 1 to 10, and subjected to surgical procedures in the femur.

Ten femurs were alternated between the right and left sides, that is, five right and five left femurs as the control group (Group I), plus five right and five left femurs forming the group to receive previously collected plasma (Group II).

\section{OBJECTIVE}

The objective of this study is to experimentally evaluate bone healing in mice, using a hemoderivative (blood plasma) to stimulate bone callus formation in bone defects produced in mice femurs. 
gicos nos fêmures.

Alternam-se o lado direito e esquerdo, tendo-se 10 fêmures (cinco direitos e cinco esquerdos como grupo controle e cinco direitos e cinco esquerdos como grupo onde é utilizado o plasma colhido previamente).

\section{OBJETIVO}

O objetivo desse trabalho é o de avaliar a consolidação óssea em estudo experimental em camundongos, com a utilização de hemoderivado (plasma) na estimulação da formação do calo ósseo, em falhas ósseas produzidas nos fêmures de camundongos.

\section{MATERIAL}

O sangue periférico de um camundongo de linhagem isogênica gioto é coletado, através de dissecção cirúrgica da aorta abdominal e punção com agulha grossa e seringa, cerca de $10 \mathrm{ml}$, sendo processado em centrifugadora para separação da fração do plasma. Este produto é utilizado para o Grupo II do experimento.

Dez camundongos isogênicos adultos de linhagem gioto, com peso aproximado de 250 gramas, provenientes do Biotério da Faculdade de Ciências Médicas Lusíadas de Santos do estado de São Paulo. Após o exame físico dos animais, os fisicamente aptos são submetidos aos procedimentos cirúrgicos. São divididos em dois grupos (I e II), sendo feito os experimentos em lados alternados.

No Grupo I estão aqueles que serão realizadas as falhas ósseas de dois milímetros do fêmur, alternadamente do lado direito e esquerdo, de tal maneira que teremos cinco fêmures de camundongos operados do lado direito e cinco do lado esquerdo, sem qualquer substituição (Grupo controle).

No Grupo II estão aqueles que serão realizadas as falhas ósseas, semelhantes ao grupo I, seguidas de colocação do concentrado de plasma obtido previamente. Temos com isso cinco fêmures direitos operados com colocação de hemoderivado e cinco do lado esquerdo.

Em resumo, temos dez camundongos, sendo vinte fêmures operados, dez do lado direito e dez do lado esquerdo, onde o Grupo I é o Grupo controle onde foram induzidas as falhas ósseas, sem qualquer substituição; e o Grupo II onde é utilizado o concentrado de plasma.

\section{MÉTODOS}

Protocolo anestésico: Os animais são anestesiados pela via intraperitonial, com Virboxil ${ }^{\circledR} 2 \%$ (Cloridrato de xilazina) na dose de $0,01 \mathrm{ml} / \mathrm{kg}$, associado a Francotar ${ }^{\circledR}$ (Quetamina) na dose de 0,50mg/100 gramas.

Técnica cirúrgica: Após tricotomia bilateral das coxas, é feita a anti-sepsia com povidine tópico a 1\% e posicionado os campos estéreis. A incisão na pele é de aproximadamente um centímetro ao nível da região distal do fêmur, diérese dos tecidos moles e controle da hemostasia.

\section{MATERIALS}

1. Approximately $10 \mathrm{ml}$ of peripheral blood of a mouse from the Gioto isogenic mouse strain were collected by surgical dissection of the abdominal aorta and puncture with a thick needle and a syringe, and centrifuged to enact blood phase separation. This product was then used in Group I/ of the trial.

2. Ten adult isogenic mice of the Goto mouse strain, weighing approximately 250 grams, provided by the Bioterium of the Lusiadas Faculty of Medical Science of Santos (Santos, SP, Brazil). After a physical evaluation, the physically able animals underwent surgical procedures and were divided into two groups (Group I and Group II); the experiments were performed on alternate sides.

Group I included the animals in whose femurs a 2-mm bone defect was induced alternating the right and left sides, so we obtained five femurs of mice that were operated in their right sides and five in their left sides, with no replacements (control group).

Group II included the animals whose bone defects were produced similarly to Group I, followed by introduction of previously obtained plasma concentrate. This gave us five operated right femurs with hemoderivative, plus five operated left femurs.

In summary, we had ten mice, therefore twenty operated femurs (ten on each side); Group I is the control group where bone defects were induced with no replacements, while in Group II the plasma concentrate was employed.

\section{METHODS}

Anesthesia protocol: All animals were intraperitoneally anesthesized using a $2 \%$ Virboxil $^{\circledR}$ (xylazine hydrochloride) solution at a dose of $0.01 \mathrm{ml} / \mathrm{kg}$ combined with Francotar ${ }^{\circledR}$ (ketamine) at a dose of $0.50 \mathrm{mg} / 100 \mathrm{~g}$.

Surgical technique: After the thighs were bilaterally trichotomized and $1 \%$ topic povidine was used as an antiseptic, sterile fields were positioned. The skin incision measured about 1 centimeter distal from the femur region, with dieresis of the soft tissues and hemostatic control.

Then a periosteal elevation was performed using a dislocator, followed by perforation of the right and left femurs one centimeter above the knee joint interline, using a drill and a titanium 2$\mathrm{mm}$ diameter drill bit using manual pressure and continuous irrigation with $0.9 \%$ saline (Figure 1A). This procedure was performed in the control group only, while the other group received injected plasma (Figure 1B). Soft tissues were sutured using 4/0 nylon monothread in isolated stitches.

After being confined in individual cages numbered from 1 to 10 , the mice received $0.1 \mathrm{~m} /$ sodium dipyrone during the first 12 hours of the postoperative period. The animals were fed standard normoprotein feed and water ad libitum and maintained in the individual cages at room temperature between 19 and $20^{\circ} \mathrm{C}$.

At two weeks of the confinement, the animals were killed and their femurs removed to prepare the specimens for qualitative 
Segue-se com a elevação periosteal com deslocador seguido de perfurações dos fêmures direito e esquerdo a um centímetro acima da interlinha articular do joelho, utilizando perfuradora com broca de titânio de dois milímetros de diâmetro, sob pressão manual e irrigação contínua com solução salina a 0,9\% (Figura 1A). No grupo controle só este procedimento é feito; no outro grupo é injetado o plasma concentrado (Figura 1B). A sutura dos tecidos moles é feita com mononylon 4-0 em pontos isolados.

Os camundongos são confinados em caixas individuais e numerados de 01 a 10 , recebendo nas 12 primeiras horas de pós-operatório $0,1 \mathrm{ml}$ de dipirona sódica. Os animais são alimentados com ração padrão normoprotéica e fornecida água "ad libitum", mantido em temperatura ambiente entre 19 e 20 graus centígrados nas gaiolas individuais.

Após duas semanas de confinamento, os animais são eutanasiados, sendo retiradas as peças (fêmures), para preparação das peças para exame anatomopatológico, sendo avaliado qualitativamente e quantitativamente do material obtido.

Protocolo de eutanásia: São realizadas as eutanásias nos grupos I e II, com os camundongos devidamente anestesiados por via intraperitonial com cloridrato de xilazina na dose $0,01 \mathrm{ml} /$ $\mathrm{kg}$, associado a quetamina na dose de 0,50mg/100 gramas. Após a anestesia é utilizada máscara inalatória com éter em dose letal, até a parada cárdio respiratória.

Protocolo de exame anatomopatológico: As peças retiradas são identificadas segundo o número do camundongo e o lado retirado, conforme protocolo do experimento. As mesmas são fixadas em formol a 10\% pelo período de doze horas e descalcificadas em ácido nítrico pelo período de 24 horas, sendo seccionadas longitudinalmente no seu maior eixo. Em seguida são identificadas segundo o protocolo e submetidas a processamento tecidual em banho seqüencial de álcool, xilol e colocadas em blocos de parafina submeti-

dos à corte histológico de quatro micras de espessura e corados com hematoxilina e eosina

São feitas duas a três lâminas por bloco e analisadas em microscópio tipo Nykon - Alpha phot número 2 com aumento de 400 vezes (figura $2 \mathrm{~A}$ e B), tendo-se como parâmetro os seguintes achados que serão levados em consideração para o

\begin{tabular}{|c|c|}
\hline Achados ao exame anatomopatológico & Pontuação adotada para avaliação \\
\hline 1. Hemorragia & $\begin{array}{l}0 \text { - focal (até um campo de } 400 \text { vezes) } \\
1 \text { - presente (mais de dois campos) }\end{array}$ \\
\hline 2. Polimorfonucleares & $\begin{array}{l}0 \text { - ausente } \\
1 \text { - presente (de } 1 \text { a } 4 \text { neutrófilos por } 10 \mathrm{HPF}^{*} \text { ) }\end{array}$ \\
\hline 3. Tecido de granulação & $\begin{array}{l}0 \text { - ausente ou escasso (até } 2 \text { campos HPF*) } \\
1 \text { - presente (acima de } 3 \text { campos HPF*) }\end{array}$ \\
\hline 4. Atividade osteoblástica & $\begin{array}{l}0 \text { - ausente ou leve (até } 2 \text { campos HPF*) } \\
1 \text { - acentuada ( } 3 \text { ou mais campos HPF*) }\end{array}$ \\
\hline 5. Matriz óssea & $\begin{array}{l}0 \text { - ausente ou focal (até } 4 \text { campos HPF*) } \\
1 \text { - presente (acima de } 5 \text { campos HPF*) }\end{array}$ \\
\hline 6. Osteoclastos & $\begin{array}{l}0 \text { - ausente ou mínima (até } 5 \text { campos HPF*) } \\
1 \text { - presente (acima de } 5 \text { campos HPF*) }\end{array}$ \\
\hline
\end{tabular}

Tabela 1 - Critérios de avaliação anatomopatológica utilizados nos achados das peças estudadas.

Table 1 - Anatomopathological evaluation criteria used for the endpoints with the studied specimens and quantitative anatomopathological evaluation of the material.

Protocol for killing mice: Mice of both Group I and Group // were killed after being intraperitoneally anesthesized with xylazine hydrochloride at a dose of $0.01 \mathrm{ml} / \mathrm{kg}$ combined with ketamine at a dose of $0.50 \mathrm{mg} / 100 \mathrm{~g}$. After the anesthesia, inhalation with ether was applied by mask using a lethal dose until cardiac and respiratory arrest was achieved.

Anatomopathological exam protocol: The specimens removed were identified according to the number of the mouse and the side that was removed, according to the study protocol. All specimens were fixed in $10 \%$ formol solution for a 12 hour period, decalcified in nitric acid for 24 hours and longitudinally sectioned along their longer axes. Then they were identified as per the protocol and the tissues were processed in baths of alcohol and xylol (in that sequence) and paraffinembedded in blocks to be sliced into 4-mm thick histological sections and stained by the hematoxyline-eosine method.

Two or three sections were produced from each block, that were then examined under a Nikon Alphaphot-2 (400x) Microscope (Figures 2A and B); we used the parameters below, that were taken into account in this study: 1. Hemorrhage; 2. Polymorphonuclears; 3. Granulation tissue; 4. Osteoblast activity; 5. Bone matrix; and 6. Osteoclasts.

\section{EVALUATION CRITERIA}

The anatomopathological evaluation was performed according to the usual parameters adopted by our Pathological Anatomy service to evaluate the inflammatory process and bone callus formation and scored for presence or absence of the findings obtained, as shown in Table 1.

\section{STATISTICAL ANALYSIS}

We observed both the absolute and relative frequencies of incidence of the anatomopathological endpoints in the sections obtained from Groups I and II. We also statistically described in both groups the quantitative parameters of he- 
presente estudo: 1. Hemorragia, 2. Polimorfonucleares, 3. Tecido de granulação, 4. Atividade osteoblástica, 5. Matriz óssea e 6. Osteoclastos.

\section{CRITÉRIOS DE AVALIAÇÃO}

A avaliação anatomopatológica segue os parâmetros habituais adotados pelo nosso Serviço de anatomia patológica, para avaliação do processo inflamatório e formação do calo ósseo, e foram pontuados, conforme a presença ou não dos achados estudados, conforme a Tabela 1.

\section{ANÁLISE ESTATÍSTICA}

Observamos a freqüência (absoluta e relativa) da incidência dos achados anatomopatológicos nas lâminas dos Grupos I e II. Realizamos a estatística descritiva dos parâmetros quantitativos nos Grupos I e II dos achados de hemorragia, polimorfonucleares, tecido de granulação, atividade osteoblástica, matriz óssea e osteoclastos.

Nas comparações dos resultados paramétricos utilizamos o teste exato de Fisher, comparando-se os eventos para cada achado do Grupo I X Grupo II. Em todos os resultados adotamos a probabilidade de significância de $5 \%(p=0,05)$ e tendência entre 5 a $10 \%(0,05<p<0,10)$.

\section{RESULTADOS}

A análise dos resultados, segundo os critérios adotados para o presente estudo encontra-se na Tabela 2, para o grupo I (controle) e grupo II (com plasma).

\section{ESTUDO COMPARATIVO}

Os resultados dos achados de hemorragia, polimorfonucleares, tecido de granulação, atividade osteoblástica, matriz óssea e osteoclastos nas lâminas do Grupo I (controle) e Grupo II (plasma) podem ser vistos na Tabela 3.

\section{DISCUSSÃO}

Estudos direcionados sobre a consolidação óssea, cada vez mais ganham ênfase dentro da Ortopedia, principalmente no que concerne à diminuição no tempo de consolidação, o que

morrhage, polymorphonuclears, granulation tissue, osteoblast activity, bone matrix and osteoclasts.

For the comparisons among parametric results we used Fisher's exact test and compared the events for each finding in Group I and Group II. For all results we adopted a 5\% p value $(\mathrm{p}=0.05)$ and a trend between 5 and $10 \%(0.05<\mathrm{p}<0.10)$.

\section{RESULTS}

Table 2 shows the results obtained using the criteria adopted in this study for Group I (control group) and Group II (with plasma concentrate).

\section{COMPARATIVE STUDY}

Table 3 shows the results of endpoints hemorrhage, polymorphonuclears, granulation tissue, osteoblast activity, bone matrix and osteoclasts in sections obtained from Group I (control group) and Group II (plasma group).

\section{DISCUSSION}

Studies directed to bone healing deserve more and more emphasis in the orthopedics area, mainly as regards the reduction in the healing time, which remains a challenge in Orthopedics. Reduce the time and

\begin{tabular}{|c|c|c|c|c|c|c|c|c|c|c|c|c|}
\hline $\begin{array}{l}\text { Achados } \\
\end{array}$ & \multicolumn{2}{|c|}{ Hemorragia } & \multicolumn{2}{|c|}{ Polimorfox. } & \multirow{2}{*}{\multicolumn{2}{|c|}{$\begin{array}{l}\text { Tecido de } \\
\text { granulaçăo }\end{array}$}} & \multicolumn{2}{|c|}{$\begin{array}{c}\text { atividade } \\
\text { osteoblastica }\end{array}$} & \multicolumn{2}{|c|}{ Matriz óssea } & \multicolumn{2}{|c|}{ Osteoclastos } \\
\hline 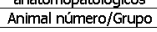 & $\mathrm{I}$ & & & II & & & & II & & & & \\
\hline 1 & 1 & 0 & 1 & 1 & 1 & 1 & 1 & 1 & 0 & 1 & 0 & 1 \\
\hline 2 & 0 & 0 & 1 & 1 & 1 & 1 & 1 & 1 & 0 & 1 & 1 & 1 \\
\hline 3 & 0 & 0 & 1 & 1 & 0 & 1 & 1 & 1 & 1 & 1 & 1 & 0 \\
\hline 4 & 0 & 0 & 1 & 1 & 0 & 1 & 1 & 1 & 0 & 1 & 0 & 1 \\
\hline 5 & 1 & 1 & 1 & 1 & 1 & 1 & 1 & 1 & 0 & 0 & 0 & 0 \\
\hline 6 & 0 & 0 & 1 & 1 & 1 & 1 & 1 & 1 & 0 & 1 & 0 & 1 \\
\hline 7 & 0 & 0 & 1 & 1 & 1 & 1 & 1 & 1 & 1 & 1 & 1 & 0 \\
\hline 8 & 0 & 0 & 1 & 1 & 1 & 1 & 1 & 1 & 1 & 1 & 1 & 1 \\
\hline 9 & 0 & 0 & 1 & 1 & 1 & 1 & 1 & 1 & 1 & 1 & 1 & 1 \\
\hline 10 & 1 & 0 & 1 & 1 & 1 & 1 & 1 & 1 & 0 & 1 & 1 & 1 \\
\hline
\end{tabular}

Tabela 2 - Resultados obtidos no grupo I (controle) e II (plasma) para cada animal de experimentação.

Table 2 - Results for Groups I (control group) e II (plasma group) for each animal.

\begin{tabular}{|c|c|c|c|c|}
\hline \multicolumn{2}{|c|}{ Achado Anatomopatológico } & \multirow{2}{*}{$\begin{array}{c}\text { Ausente } \\
0 \text { (número) } \\
7\end{array}$} & \multirow{2}{*}{$\begin{array}{c}\text { Presente } \\
1 \text { (número) } \\
3\end{array}$} & \multirow{2}{*}{$\begin{array}{c}\text { Teste estatístico } \\
\text { P (Fischer) }\end{array}$} \\
\hline Hemorragia & Grupo I & & & \\
\hline & Grupo II & 9 & 1 & $P=0,582 \mathrm{NS}$ \\
\hline \multirow[t]{2}{*}{ Polimorfonucleares } & Grupo I & 0 & 10 & \\
\hline & Grupo II & 0 & 10 & $P=1,000 \mathrm{NS}$ \\
\hline \multirow[t]{2}{*}{ Tecido de granulaçăo } & Grupo I & 2 & 8 & \\
\hline & Grupo II & 0 & 10 & $P=0,474 \mathrm{NS}$ \\
\hline \multirow[t]{2}{*}{ Atividade osteoblástica } & Grupo I & 0 & 10 & \\
\hline & Grupo II & 0 & 10 & $P=1,000 \mathrm{NS}$ \\
\hline \multirow[t]{2}{*}{ Matiz óssea } & Grupo I & 6 & 4 & \\
\hline & Grupo II & 1 & 9 & $P=0,057^{*}$ \\
\hline \multirow[t]{2}{*}{ Osteoclastos } & Grupo I & 4 & 6 & \\
\hline & Grupo II & 3 & 7 & $P=1,000 \mathrm{NS}$ \\
\hline
\end{tabular}

Tabela 3: Análise estatística dos achados anatomopatológicos pelo teste de Fischer.

ysis of anatomopathological endpoints by use biological syntheses in the management of pseudoarthroses are a challenge to all professionals involved, and fully justify trials such as the present one ${ }^{(4)}$.

Ham and Harris( ${ }^{(4)}$ used rabbitt ribs to describe a process that is similar to that of humans in terms of healing, and reported that such processes are comparable, at least as regards the aspects studied; the stages described by those authors served as a base for our study.

McKibbin ${ }^{(6)}$ made a rather complete review of certain aspects of the tubular bone repair, which is quite different from the spongy bone repair, and reached the conclusion that the type of healing of a given bone is influenced by various factors such as rigid fixation and a perfect reduction of the fragments.

In rabbits with intramedu-

Table 3 - Statistical analysis of anatomo
Fisher's test. 
ainda é um desafio na Ortopedia. Diminuir o tempo e usar sínteses biológicas no tratamento de pseudoartroses são um desafio para todos os profissionais envolvidos e justificam plenamente experimentos como este ${ }^{(4)}$.

Ham e Harris ${ }^{(4)}$ descreveram em fraturas de costelas em coelhos um processo semelhante ao homem, em termos de consolidação e relataram que ao menos quanto às condições estudadas, estas são comparáveis, descrevendo suas etapas que servem de base para o presente estudo.

McKibbin $^{(6)}$ revisou aspectos de maneira bastante completa quanto à reparação de um osso tubular, que difere muito da reparação de um osso esponjoso, concluindo que o tipo de consolidação de um determinado osso é influenciado por diversos fatores como a fixação rígida e a perfeita redução dos fragmentos.

Tavares e Cafalli(9) observaram em coelhos com osteossíntese intramedular implantada no fêmur em um defeito ósseo induzido, a consolidação precoce desta falha óssea com esta osteossíntese; também nos fundamentamos nestas etapas para o seguimento do experimento.

Croci(3) $^{(3)}$ em revisão da literatura, discorre sobre a BMP ("bone morphogenetic protein") que teria ação em quatro etapas de diferenciação específica, com a formação de osso primitivo lamelar, mas só experimentalmente, sem desenvolver a etapa específica a qual ela deva ser introduzida; esta proteína poderia estar presente inclusive nos elementos sangüíneos que poderiam ser usados como estimuladores da formação do calo ósseo.

A utilização do plasma concentrado como estímulo para a consolidação óssea, além do fato descrito acima, também se deve ao fato da facilidade da obtenção deste plasma no próprio paciente, sendo uma opção biológica não acarretando maiores complicações ao paciente.

Para uma melhor obtenção do concentrado do plasma, utilizamos um camundongo isogênico, que é geneticamente igual aos animais do experimento, evitando-se com isso potencial reação imunogênica que pudesse interferir no trabalho. O objetivo deste é testar a utilização cruzada do plasma no teste de formação do calo ósseo.

Uniformizamos o método usado para a falha óssea e alternamos os lados dos fêmures (direito e esquerdo) para evitarmos uma eventual predominância do membro, e ao mesmo também empregamos no pós-operatório o acompanhamento com a mesma bióloga para alimentação e cuidados com os camundongos pelo período de confinamento.

Utilizamos como protocolo anestésico, a via intraperitonial utilizando a associação de quetamina e cloridrato xilazina pela facilidade e controle do animal; a técnica cirúrgica foi cuidadosamente executada com o mesmo padrão e equipe para não ocorrer discrepância de técnica; a eutanásia também é feita com o mesmo método anestésico e terminada com a inalação de éter até parada cárdio respiratória do animal.

O padrão utilizado para a avaliação anatomopatológica foi aquele seguido pela maioria dos patologistas e seguidos na análise de todas as lâminas do trabalho.

Em virtude da área da fratura ser pequena o número de campos microscópicos não ultrapassou cinco campos HPF por uma llar osteosyntheses inserted in the femur in an induced bone defect, Tavares and Cafalli(9) observed that the osteosyntheses caused an early healing of this bone defect, and we also based our trial on these stages.

In a literature review, Croci(3) described BMP (the bone morphogenetic protein) that would act in four specifically differentiated stages, with the formation of lamellar primitive bone, although experimentally only, with no details about the specific stage when the BMP should be introduced; this protein might be present even in the blood elements that might be used to stimulate bone callus formation.

Besides the above-mentioned fact, we used plasma concentrate to stimulate bone healing also because this plasma can be easily obtained from patients themselves, being thus a biological alternative that does not bring any relevant complications to the patient.

In order to better obtain the plasma concentrate, we used an isogenic mouse, which is genetically equal to the animals of the trial; this prevented the presence of a potential immunogenic reaction capable of interfering with the study. The objective of the study was to test the crossed use of plasma in the test of bone callus formation.

The method was homogeneized for bone defect and the right and left femurs were alternated to prevent the predominance of either member; also, during the postoperative period, the same biologist monitored the feeding and care of the mice while they were confined.

The anesthesia protocol consisted of an intraperitoneally administered combination of ketamine plus xylazine hydrochloride, because it is easy to use and the animals can be controlled; the surgical technique was carefully applied always with the same pattern and by the same team if order to prevent discrepancies; the rats were killed using the same anesthetic combination followed by ether inhalation until the final respiratory and cardiac arrest.

The pattern used for the anatomopathological evaluation was the one used by most pathologists, being followed by the analysis of all sections prepared during the trial.

Because the fracture area was small, the number of miroscope fields did not exceed five HPFs in a $0.5-\mathrm{cm}$ long area of each section analyzed.

During the bone repairment processes, established anatomopathological criteria were used and the alterations below were observed.

A - Hemorrhage: After the bone injury, cells become damaged, mainly the blood vessels, when blood overflows into the medullar canal in the presence of local hemosiderin. Where no differences were noticed between Groups I and II analyzed, hemorrhage was evaluated as absent or focal (up to one field) and present (more than two fields).

$B$ - Polymorphonuclears: Inflammatory mediators released by the dead and injured cells cause blood vessels to dilate and exsudate plasma, with the formation of inflammatory cells such as polymorphonuclear cells, or neutrophils. The evaluation parameters used were absent (0) and present (1 to 4 neutrophils per 10 HPFs). No differences were noticed between Groups I and /I analyzed. 
área de 0,5 cm de extensão na lâmina analisada.

Dentro dos processos de reparação óssea foram utilizados critérios anatomopatológicos estabelecidos diante das seguintes alterações:

A - Hemorragia: Após a lesão óssea, ocorre dano nas células principalmente vasos sangüíneos, o que ocorre com o extravasamento sangüíneo dentro do canal medular com a presença de hemossiderina local. Foram avaliados como ausente ou focal (até um campo) e presente (mais de dois campos), onde não houve diferença entre os grupos I e II analisados.

B - Polimorfonucleares: Os mediadores inflamatórios liberados pelas células mortas e lesadas fazem com que os vasos sangüíneos dilatem-se e exsudem o plasma, com aparecimento de células inflamatórias como os polimorfonucleares (neutrófilos). Foram usados como parâmetros para avaliação como ausente (0) e presente (de 1 a 4 neutrófilos por 10HPF), e não houve diferença entre os grupos I e II estudados.

C - Tecido de Granulação: Na fase de reparação tecidual, caracteriza-se o tecido de granulação pelo aparecimento de fibroblastos e neovascularização, como resultado de mediadores químicos presentes. Foi utilizado como critério de avaliação o ausente ou escasso (até 2 campos HPF) e o presente (acima de 3 campos HPF), não observando alterações entre os grupos.

D - Osteoblastos: De origem das células do estroma medular, responsáveis pela síntese de matriz para reparos e crescimento, morfologicamente contêm o aparelho de Golgi, retículo endoplasmático e canalículos em grandes quantidades tendo como função principal a osteogênese. O padrão utilizado para sua análise foi o ausente ou leve (até 2 campos HPF) e o presente ( 3 ou mais campos HPF), não sendo observada dentro da analise qualquer diferença entre os grupos.

E - Matriz Óssea: Compreende cerca de um terço da massa óssea, sendo responsável pela viscoelasticidade e força tensil do osso. O colágeno tipo I compreende $90 \%$ da matriz e a hidroxiprolina é um produto da sua degradação, dando origem ao tecido ósseo maduro. Para análise usamos os parâmetros de ausente ou focal (até 4 campos HPF) e presente (acima de 5 campos HPF), não sendo observada diferença significante pelo parâmetro estatístico de 5\%, mas muito próximo deste ( $\mathrm{P}=$ 0,057); há, portanto, uma tendência para que o uso de concentrado de plasma produza mais matriz óssea, necessitando-se provavelmente de um experimento com UM "N" maior ou talvez que a quantidade de elementos estimulantes presentes no plasma seja muito pequena para o completo estímulo. Necessitaríamos de outros experimentos com diferenciação talvez dos sub tipos de proteínas morfogenéticas para conclusões posteriores.

F - Osteoclastos: Estes são células maiores, derivadas de macrófagos ou do sistema hematopoiético, que contêm enzimas lisossômicas, como a fosfatase ácida, a colagenase e a catepsina, sendo as principais células no processo de remodelação óssea. Utilizamos como padrão para avaliação o ausente ou mínima (até 5 campos HPF) e o presente (acima 5 campos HPF), não observando diferença entre os grupos I e II.

Para os resultados adotamos o índice de significância de $5 \%(p=0,05)$, sendo padrão para todas as análises, sendo este parâmetro adotados pela maioria dos trabalhos científicos.

Os achados em relação à matriz óssea mostraram uma possível aceleração do processo de osteogênese, principalmente
C - Granulation tissue: During the tissue repair stage the granulation tissue characterizes by the appearance of fibroblasts and neovascularization as a result of the presence of chemical mediators. The evaluation criterion used was absent or scarce (up to 2 HPFs) and present (more than 3 HPFs). No differences were noticed between groups.

$D$ - Osteoblasts: Originating from the medullar stroma and responsible for the synthesis of the matrix for repair and growth, morphologically osteoblasts include Golgi's apparatus, the endoplasmic reticulum and large amounts of canaliculi, their main function being osteogenesis. The criteria used to analyze them were absent or mild (up to 2 HPFs) and present (3 or more HPFs). No differences were noticed between the groups analyzed.

E - Bone matrix: Includes about one third of the bone mass and is responsible for bone viscoelasticity and tensile forces. Type 1 collagen includes $90 \%$ of the matrix, and degrades into hydroxyproline, giving origin to mature bone tissue. For the analysis we used the absent or focal parameters (up to 4 HPFs) and present (more than 5 HPFs). No significant differences were noticed according to the specific 5\% parameter, but very close to it $(\mathrm{p}=0.057)$; therefore, a tendency exists to use plasma concentrate to produce more bone matrix, and probably a trial would be required with a higher number of individuals; or maybe the amount of stimulating elements present in the plasma is too small to achieve complete stimulation. Also, in order to reach further conclusions, more trials would be required, perhaps differentiating morphogenetic protein subtypes.

F- Osteoclasts: These are larger cells that derive from macrophages or from the hematopoetic system that includes lysosome enzymes such as acid phosphatase, collagenase and catepsin. Osteoclasts are the mains cells in the bone remodeling process. The parameters used to evaluate osteoclasts were absent or minimal (up to 5 HPFs) and present (more than 5 HPFs). No differences were noticed between the groups analyzed.

The $5 \%$ significance value $(\mathrm{p}=0.05)$ was used in all analyses, since this is the parameter adopted in most scientific papers.

The bone matrix results showed a possible acceleration in the osteogenesis process, mainly as regards osteoid bone formation in animals exposed to plasma concentrate stimulation. This may correspond to a higher speed in the process of bone callus formation.

For the rest of the elements studied, no different responses were found between the control group and the plasma group. Various factors may have contributed for these results. We believe that a higher number of animals might provide significance to some of the studied elements or, perhaps, a higher plasma depuration, in order to increase the plasma concentration of factors stimulating bone callus formation. This is a rather expensive resource that still does not exist in our area, making it impossible to perform many trials.

Based on this, it seems more appropriate to use a methodology including osteoclast and osteoblast counts and possibly immunohistochemical methods to assess cell proliferation, for a more ample approach.

We believe that in the future, with improved techniques and better understanding of the healing steps, it will be possible to have trials based on the use of various substances, among them plasma itself, that will have practical application in Orthopedics 
no que se refere na formação de tecido osteóide nos animais expostos à estimulação do concentrado de plasma. Isto pode corresponder a uma maior velocidade no processo de formação do calo ósseo.

Para os demais elementos estudados não encontramos uma resposta diferente entre o grupo controle e o grupo onde foi utilizado o plasma. Vários fatores podem ter contribuído para estes resultados. Acreditamos que um número maior de animais poderia tornar significante mais algum elemento estudado, ou talvez uma depuração maior do plasma, no sentido de aumentar a concentração plasmática dos fatores estimulantes da formação de calo ósseo. Isto em nosso meio ainda é um recurso inexistente e extremamente oneroso, impossibilitando a confecção de vários trabalhos.

Diante disto, nos parece mais apropriado a utilização de uma metodologia que inclui a contagem de osteoclastos e osteoblastos e eventuais métodos de imunoistoquímica com avaliação da proliferação celular para uma abordagem mais ampla.

No futuro acreditamos que com a melhora da técnica e entendimento dos passos de consolidação, possamos ter trabaIhos que derivem do emprego de várias substâncias, dentre as quais o próprio plasma possa fazer parte, tendo aplicação prática no meio ortopédico e cirúrgico para a cura e reparo de várias lesões, como fraturas, retardo de consolidação e mesmo pseudoartroses

\section{CONCLUSÕES}

1. O uso de concentrado de plasma em falhas ósseas de fêmures de camundongos, não leva a estimulação da formação do calo ósseo.

2. Não há aumento do processo inflamatório no local das falhas ósseas, com o uso de concentrado de plasma.

3. Há uma tendência em formar mais matriz óssea com o uso de concentrado de plasma. and Surgery, to heal and repair many types of injuries such as fractures, healing delay and even pseudoarthroses.

\section{CONCLUSIONS}

1. The use of plasma concentrate in bone defects of mice femurs does not lead to stimulation of bone callus formation.

2. The use of plasma concentrate does not increase the inflammatory process at bone defect sites.

3. The use of plasma concentrate promotes a tendency to form more bone matrix.

\section{REFERÊNCIAS BIBLIOGRÁFICAS}

1. Buckwalter JA, Cooper RR. Bone structure and function. Instr Course Lect 36: 27-48, 1987

2. Burstein AH, Zika JM, Heiple KG, Klein L. Contribuition of collagen and mineral to the elastic-plastic properties of bone. J Bone Joint Surg Am 57: 956-961, 1975

3. Croci AT. Retarde de consolidação e pseudoartrose. Acta Ortop Bras 5: 26-34, 1997.

4. Ham AW, Harris WR. Repair and transplantation of bone. In: Bourne G. ed. The biochemistry and physiology of bone. $2^{\text {nd }}$. New York: Academic Press, 1971. p. 337-393

5. Kato A, Bishop JE, Norman AW. Evidence for 1 alpha,25-dihydroxyvitamin D3 receptor/binding protein in a membrane fraction isolated from a chick tibial fracture-healing callus. Biochem Biophys Res Commun 244: 724-727, 1998.
6. Mckibbin B. The biology of fracture healing in long bones. J Bone Joint Surg Br 60: 150-162, 1978.

7. Santos Neto FL, Volpon JB. Experimental nonunion in dogs. Clin Orthop 187: 260-271, 1984.

8. Schatzker J, Waddell J, Stoll JE. The effects of motion on the healing of cancellous bone. Clin Orthop 245: 282-287, 1989.

9. Tavares GF, Cafalli FAS. Resposta osteogênica por lesão esquelética a distância: estudo experimental em coelho. Rev Bras Ortop 29: 416-420, 1994 10. Trueta J. Nonunion of fractures. Clin. Orthop., 43: 23-35, 1965

11. Urist MR, Lietze A, Mizutani $H$. et al. A bovine low molecular weight bone morphogenetic protein (BMP) fraction. Clin Orthop 162: 219-232, 1982.

12. Yamazaki M, Nakajima F, Ogasawara A. Spatial and temporal distribution of CD 44 and osteopontin in fracture callus. J Bone Joint Surg Br 81: 508 $515,1999$. 